\title{
IMPLEMENTASI ALGORITMA FISHER YATES SHUFFLE PADA GAME PENGENALAN BUAH DAERAH INDONESIA
}

\author{
Yati Nurhayati ${ }^{1}$ \\ ${ }^{1}$ Fakultas Ilmu Komputer Universitas Kuningan \\ E-mail: $*^{1}$ yati.nurhayati@uniku.ac.id
}

\begin{abstract}
Abstrak
Setiap negara memiliki ciri khas baik dari segi budaya, alam dan lain sebagainya. Jika dikembangkan dengan baik maka dapat menjadi salah satu aset untuk menaikan pendapatan negara tersebut. Negara Indonesia salah satu negara yang kaya akan ragam budayanya, hal ini dapat dilihat salah satunya dari beraneka ragamnya jenis makanan di masing-masing daerah contohnya adalah buah-buahan. Akan tetapi masih banyaknya buah-buahan Indonesia yang belum dikenal baik bagi warga negara Indonesia sendiri maupun mancanegara. Oleh karena itu pada penelitian ini dibuat sebuah aplikasi dalam bentuk game untuk mengenalkan buah-buahan Indonesia. Sehingga dapat lebih mengenalkan ciri khas Indonesia lebih luas lagi ke masyarakat. Pada aplikasi ini diterapkan algoritma Fisher Yates Shuffle untuk pengacakan string soal agar lebih menarik. Perancangan sistem menggunakan Unified Model Language (UML) dan ditepkan ke dalam bahasa pemrograman php dan mysql (untuk sisi admin) sedangkan untuk sisi pengguna dapat mengakses menggunakan mobile.
\end{abstract}

Kata Kunci-Game, Buah Indonesia, LCM, UML

\begin{abstract}
Each country has characteristics both in terms of culture, nature and so forth. If it is well developed, it can become one of the assets to increase the country's income. Indonesia is one country that is rich in cultural diversity, this can be seen from one of the various types of food in each region, for example fruit. However, there are still many Indonesian fruits that are not yet well known to both Indonesian and foreign citizens. Therefore in this study an application was made in the form of a game to introduce Indonesian fruits. So that it can introduce Indonesian characteristics more broadly to the public. In this application the Linear Fisher Yates Shuffle algorithm is applied to randomize the question string to make it more interesting. The system design uses the Unified Model Language (UML) and placed in the php and mysql programming languages (for the admin side) while for the user side can access using mobile.
\end{abstract}

Keywords - Game, Indonesia Fruits, LCM, UML

\section{PENDAHULUAN}

Keanekaragaman suatu negara merupakan salah satu aset tersebar yang jika dikembangkan dapat meningkatkan perekonomian bangsa tersebut. Salah satu negara dengan keanekaragaman terbesar adalah Indonesia. Indonesia tidak hanya terkenal dengan budaya yang beraneka ragam tetapi juga terkenal akan flora dan fauna nya. Salah satu jenis flora yang saat 
JURNAL BUFFER INFORMATIKA

Volume 5 Nomor 1, April 2018

ini hampir punah adalah flora jenis buahbuahan dimana sebagian besar tanaman tersebut dapat dijadikan sebagai obat alami untuk mengobati berbagai penyakit.

Kelangkaan tanaman tersebut sebagian besar diakibatkan oleh kurangnya pengetahuan di masyarakat saat ini diakibatkan masyarakat lebih mempercayai obat-obatan kimia. Padahal banyak jenis tanaman buah-buahan di daerah Indonesia yang menjadi ciri khas Indonesia itu sendiri dimana negara lain tidak ada.

Oleh sebab itu, untuk meningkatkan pengetahuan serta kepedulian masyarakat terhadap flora di Indonesia maka pada penelitian ini dirancang sebuah aplikasi yang dapat menampilkan data-data buah khas Indonesia, dan agar lebih menarik dikemas ke dalam sebuah game agar anak sekolah dasar dapat memainkannya juga, yang tercantum dalam judul penelitian "Implementasi Algoritma Fisher Yates Shuffle pada Game Pengenalan Buah Daerah Indonesia“

\section{METODE PENELITIAN}

\subsection{GDLC}

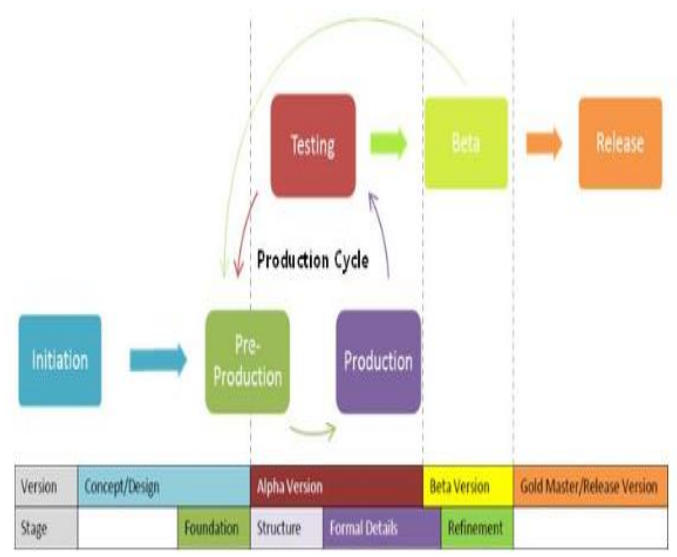

\section{Gambar 1. GDLC [1]}

Game development life cycle adalah sebuah metode pembangunan dan pengembangan game, dimana di dalamnya ada tahapan initiation, pre-production, production, testing, beta, dan release, berikut penjelasan tentang tahapan-tahapan
p-ISSN : 2527-4856, e-ISSN : 2614-5413

https://journal.uniku.ac.id/index.php/buffer

game development life cycle yang bisa disingkat GDLC[1].

\subsubsection{Teknik Pengumpulan Data}

Teknik pengumpulan data yang digunakan dalam penelitian ini adalah menggunakan Studi Pustaka, dimana pada teknik ini, data dikumpulkan dengan mempelajari berbagai dokumen, jurnal dan beberapa literature lainnya yang berkaitan dengan permasalahan yang diteliti mengenai game, algoritma fisher yates shuffle, buah khas daerah di Indonesia.

\subsubsection{Algoritma Fisher Yates Shuffle}

Fisher-Yates Shuffle (dinamai berdasarkan penemunya, Ronald Fisher danFrank Yates) digunakan untuk mengubah urutan masukan yang diberikan secara acak. Permutasi yang dihasilkan oleh algoritma ini muncul dengan probabilitas yang sama. Metode dasar yang diberikan untuk menghasilkan permutasi acak dari angka 1 - $\mathrm{N}$ berjalan sebagai berikut:

a. Tuliskan angka dari 1 sampai $n$

b. Isi nilai $\mathrm{k}$ dengan bilangan acak antara 0 hingga $i+1$ bulatkan kebawah

c. hitung dari low end, gantikan nilai $\mathrm{k}$ dan tuliskan di tempat lain

d. Ulangi dari langkah 2 sampai semua nomor digantikan

e. Urutan angka yang tertulis di langkah 3 sekarang permutasi acak dari nomor asli.

f. Pada versi yang baru (modern) angka yang terpilih tidak dicoret, tetapi ditukar posisinya dengan angka terakhir dari angka yang belum terpilih

Range adalah jumlah angka yang belum terpilih, rolladalah angka acak yang terpilih, scratch adalah daftar angka yang belum terpilih, result adalah hasil permutasi yang akan didapatkan. 


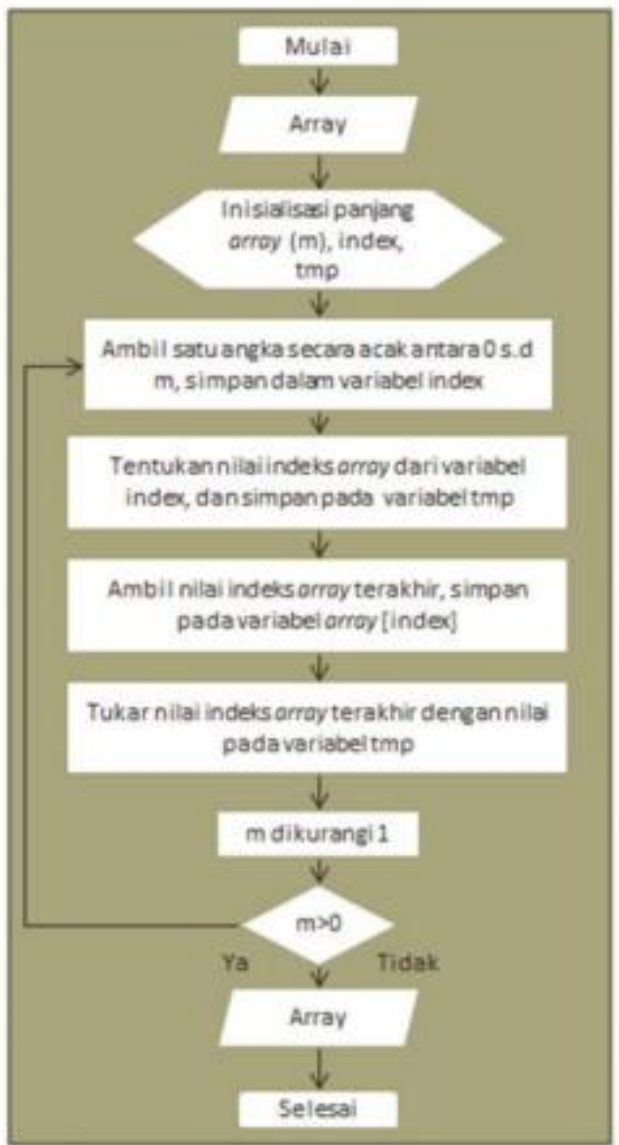

\section{Gambar 2. Flowchart Algoitma Fisher} Yates [2]

\subsection{3. $U M L$}

Unified Modeling Language (UML) adalah sebuah bahasa pemodelan yang digunakan untuk menentukan atau mendeskripsikan sebuah sistem software berdasarkan objek-objek yang ada di sistem tersebut. UML tidak menentukan metode apa yang harus digunakan dalam mengembangkan suatu sistem, namun hanya menentukan notasi-notasi standar yang biasa digunakan untuk object modeling. [3]

Dibawah ini merupakan penjelasan sigkat mengenai diagram-diagram UML

a. Use Case Diagram sebuah diagram yang mendeskripsikan interaksi antara sistem dengan bagian eksternal dari sistem serta dengan user.
p-ISSN : 2527-4856, e-ISSN : 2614-5413

https://journal.uniku.ac.id/index.php/buffer

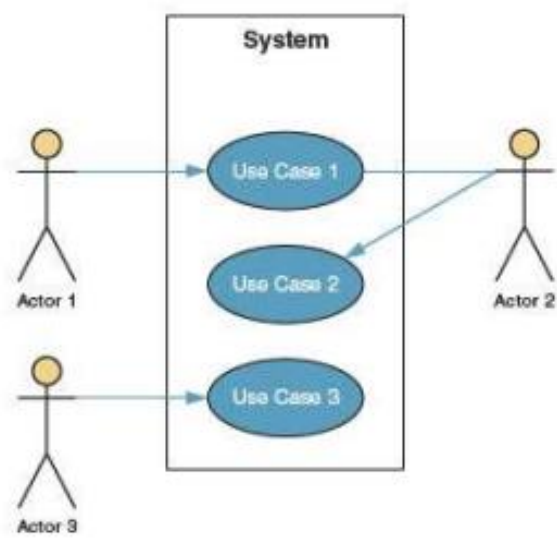

Gambar 3. Use Case Diagram

b. Activity Diagram untuk memodelkan perilaku Use Cases dan objects di dalam system.

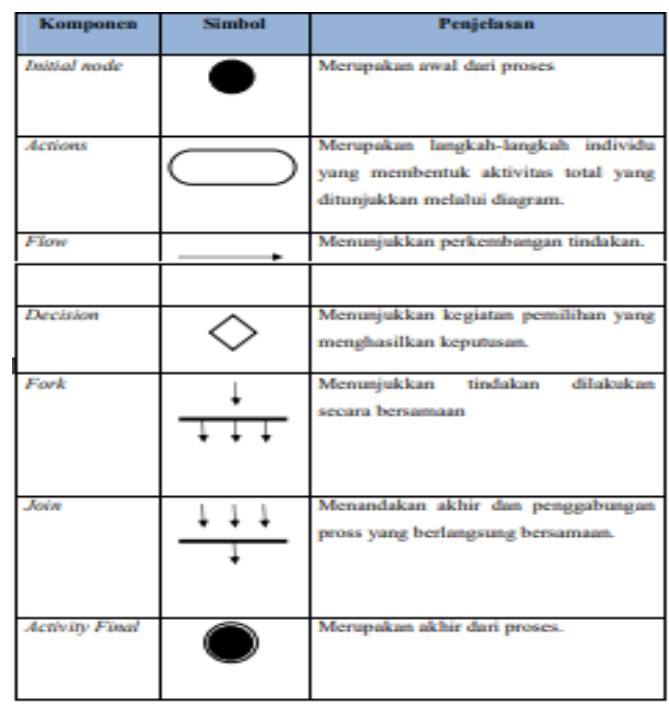

Gambar 4. Activity Diagram

c. Class Diagram untuk memodelkan struktur kelas 
JURNAL BUFFER INFORMATIKA

Volume 5 Nomor 1, April 2018

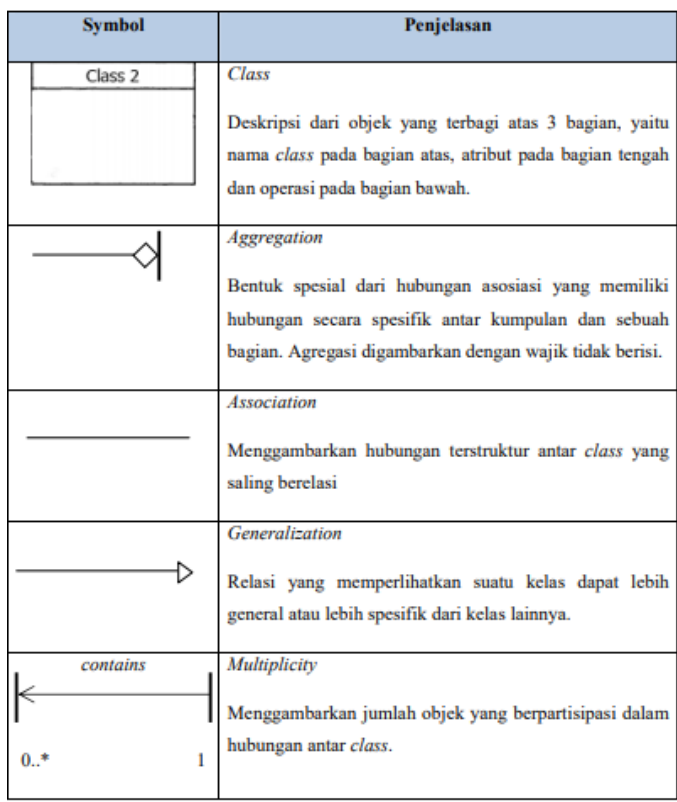

Gambar 5. Class Diagram

\section{HASIL DAN PEMBAHASAN}

Adapun hasil dan pembahasan dari penelitian ini adalah:

a. Algoritma Fisher Yates Shuffle Contoh soal : buah CARICA

\section{Tabel 1. Contoh soal acak}

\begin{tabular}{|c|c|c|c|c|c|c|}
\hline STRING & C & A & $\mathrm{R}$ & 1 & $\mathrm{C}$ & A \\
\hline INDEX & 0 & 1 & 2 & 3 & 4 & 5 \\
\hline
\end{tabular}

Tabel 2. Perhitungan Dengan Fisher Yates

\begin{tabular}{|c|c|c|c|c|}
\hline \multirow{2}{*}{ Range } & \multirow{2}{*}{ Roll } & \multirow{2}{*}{ Scratch } & \multicolumn{2}{|c|}{ Results } \\
\hline & & & index & String \\
\hline $1-5$ & 1 & $0,5,2,3,4$ & 1 & A \\
\hline $1-4$ & 0 & $4,5,2,3$ & 0,1 & $\mathrm{C}, \mathrm{A}$ \\
\hline $1-3$ & 2 & $4,5,3$ & $2,0,1$ & $\mathrm{R}, \mathrm{C}, \mathrm{A}$ \\
\hline $1-2$ & 5 & 4,3 & $5,2,0,1$ & $A, R, C, A$ \\
\hline 1 & 3 & 4 & $3,5,2,0,1$ & $\mathrm{I}, \mathrm{A}, \mathrm{R}, \mathrm{C}, \mathrm{A}$ \\
\hline \multicolumn{3}{|c|}{ Hasil Akhir } & $4,3,5,2,0,1$ & $C, I, A, R, C, A$ \\
\hline
\end{tabular}

p-ISSN : 2527-4856, e-ISSN : 2614-5413

https://journal.uniku.ac.id/index.php/buffer

b. Perancangan Sistem

- Use Case Diagram

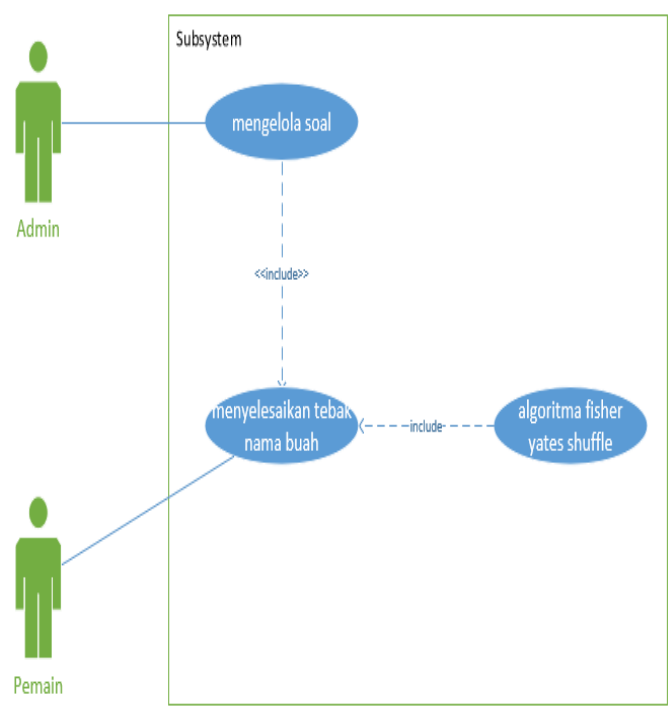

Gambar 6. Use Case Diagram

- Activity Diagram

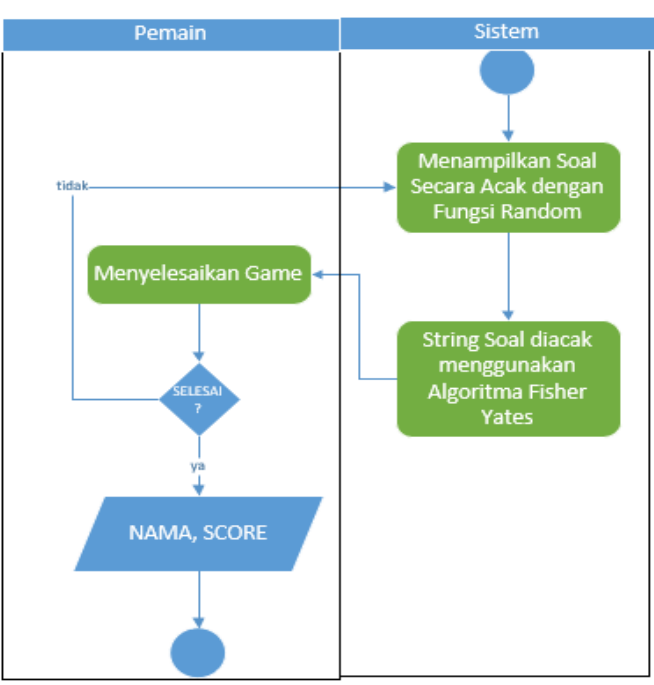

Gambar 7. Activity Diagram

c. Implementasi

Admin :

- Data Buah Indonesia 
JURNAL BUFFER INFORMATIKA

Volume 5 Nomor 1, April 2019



Gambar 8. Data Buah

- Tambah Data Buah

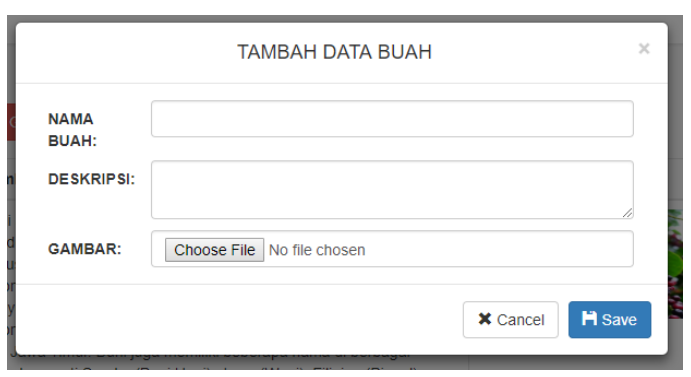

Gambar 9. Tambah Data Buah

Pengguna :

- Menu Utama

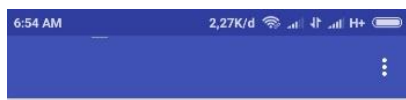

GAME TEBAK BUAH

KHAS DAERAH DI INDONESIA
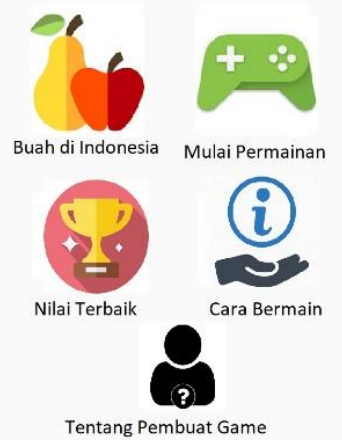

Gambar 10. Menu Utama Android
p-ISSN : 2527-4856, e-ISSN : 2614-5413

https://journal.uniku.ac.id/index.php/buffer

- Deskripsi Buah

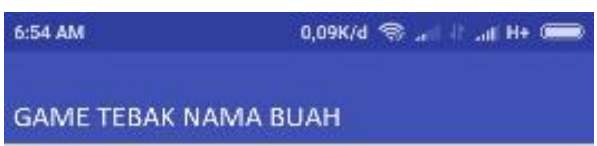

DESKRIPSI

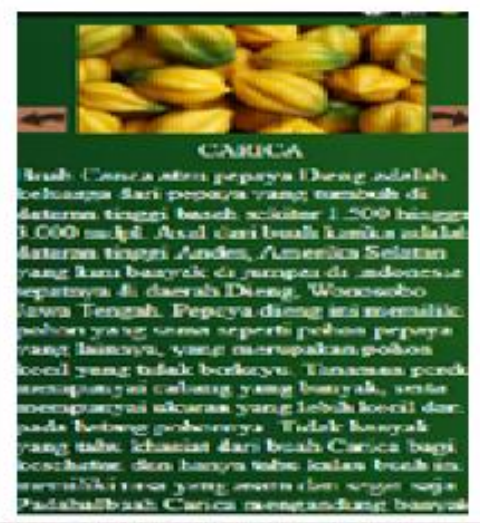

Gambar 11. Deskripsi Buah Daerah Indonesia

- Game Tebak Buah

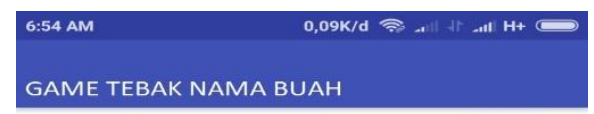

00.30

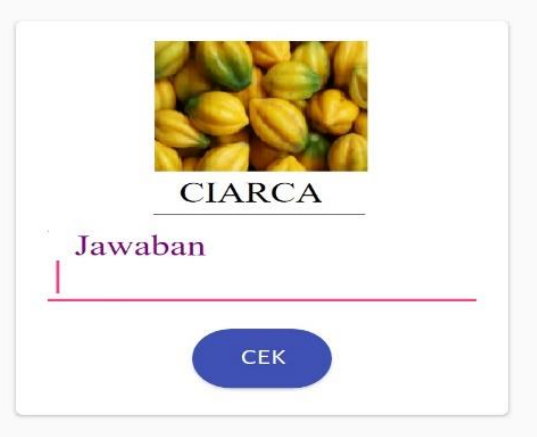

Gambar 12 Game Tebak Buah 
- Skor

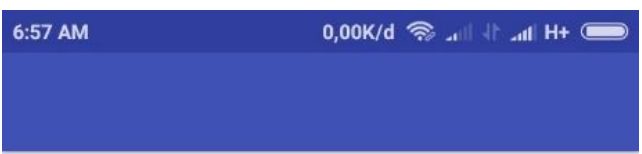

MASUKAN NAMA

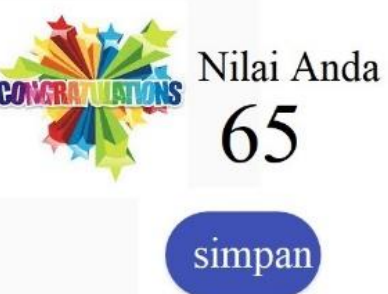

\section{Gambar 13. Skor Nilai Akhir Permainan}

\section{KESIMPULAN}

ini adalah:

Adapun kesimpulan dari penelitian

1. Dengan menggunakan Algoritma Fisher Yates Shuffle, dapat dilakukan pengacakan soal secara optimal dimana index yang dihasilkan tidak berulang.

2. Penelitian ini berhasil mengimplementasikan algoritma fisher yates ke dalam bentuk game berbasis android

3. Aplikasi ini mampu menarik minat masyarakat khususnya anak sekolah dasar kelas 5 untuk mempelajari ragam buah-buahan khas daerah di Indonesia.

\section{SARAN}

Agar penelitian yang dihasilkan lebih optimal, maka diharapkan :

1. Adanya pengembangan lebih lanjut mengenai algoritma untuk pencocokan jawaban.

2. Menambahkan kesempatan (nyawa) dalam permainan
p-ISSN : 2527-4856, e-ISSN : 2614-5413

https://journal.uniku.ac.id/index.php/buffer

\section{UCAPAN TERIMA KASIH}

Serta penulis mengucapakan terima kasih kepada semua pihak yang telah membantu sehingga penelitian ini dapat selesai tepat pada waktunya.

\section{DAFTAR PUSTAKA}

[1] Ramadan, Rido. Game Development Life Cycle. 2013.

[2] Supriyanto. Penerapan Algoritme Fisher-Yates pada Edugame Guess Caculation Berbasis Android. Palembang : STMIK GI MDP.

[3] Bentley, Lonnie D, dan Jeffrey L Whitten. 2007. Systems. Analysis and Design for the Global Enterprise Seventh Edition,. New York: McGraw-Hill. 